\title{
SUPERVISI KEPALA SEKOLAH TERHADAP PENINGKATAN KINERJA GURU
}

\author{
Junia Putri
}

juniaputri915@gmail.com

\begin{abstract}
ABSTRAK
Supervisor pendidikan salah satu kompetensi yang harus dimiliki kepala sekolah, kepala sekolah yang mempunyai kompetensi supervisor pendidikan adalah kepala sekolah yang dapat bertanggung jawab dan berperan dalam membantu guru dalam meningkatkan kinerjanya secara maksimal. Sekolah memiliki sumber daya dalam mencapai tujuan pendidikan salah satunya yaitu guru. Guru memainkan peran dalam keberhasilan dalam mencapai tujuan sekolah, oleh sebab itu kepala sekolah harus membantu guru dalam proses pembelajaran. Supervisi kepala sekolah yang dilaksanakan secara tepat dapat membantu untuk peningkatan kinerja guru dalam melakukan tugasnya sebagai seorang pendidik. Ketidaktepatan pelaksanaan supervisi membuat guru menjadi acuh yang pada akhirnya akan membuat kinerja guru menurun sehingga berdampak pada tidak tercapainya tujuan pendidikan.
\end{abstract}

Kata kunci: supervisi kepala sekolah, peningkatan kinerja guru

\section{LATAR BELAKANG}

Supervisi akademik adalah supervisi yang dilaksanakan oleh kepala sekolah terhadap proses pembelajaran. Supervisi akademik dapat dilakukan oleh kepala sekolah maupun oleh pengawas. Pelaksanaan supervisi oleh kepala sekolah akan membuat kegiatan pengawasan lebih intensif karena pemahaman kepala sekolah terhadap kebutuhan guru. Misi utama supervisi pendidikan adalah memberi pelayanan kepada guru untuk mengembangkan mutu pelajaran, memfasilitasi guru agar dapat mengajar dengan efektif. Istilah supervisi pembelajaran merujuk kepada pengertian memperbaiki mutu kegiatan pokok di sekolah, yaitu perbaikan proses belajar mengajar atau pembelajaran atau disebut juga "Instructional". Supervisi pengajaran merupakan fungsi penting dalam sistem pendidikan yang mengefektifkan seluruh unsur-unsur pengajaran kedalam aktivitas pendidikan, supervisi bergerak dalam bidang akademik.

Supervisi akademik adalah serangkaian kegiatan untuk membantu guru mengembangkan kemampuannya mengelola proses pembelajaran demi pencapaian tujuan pembelajaran. Supervisi 
akademik merupakan upaya membantu guru-guru mengembangkan kemampuannya mencapai tujuan pembelajaran. Esensi supervisi akademik itu sama sekali bukan menilai unjuk kerja guru dalam mengelola proses pembelajaran, melainkan membantu guru mengembangkan kemampuan profesionalnya. Supervisi akademik ditinjau dari objek yang di supervisi lebih menitik beratkan pengamatan supervisor pada masalah-masalah akademik, yaitu hal-hal yang langsung berada dalam lingkungan kegiatan pembelajaran pada waktu siswa sedang proses mempelajari sesuatu. Supervisi akademik merupakan kegiatan pembinaan dengan memberi bantuan teknis kepada guru dalam melaksanakan proses pembelajaran, yang bertujuan untuk meningkatkan kemampuan profesional guru dan meningkatkan kualitas pembelajaran.

Berdasarkan pada tujuan supervisi akademik, maka perlu diketahui fungsi supervisi akademik. Supervisi akademik mempunyai fungsi penilaian (evaluation) yaitu penilaian kinerja guru dengan cara penelitian (reseach) yaitu pengumpulan informasi dan fakta-fakta mengenai kinerja guru dengan cara melakukan penelitian. Kegiatan evaluasi dan penelitian ini merupakan usaha perbaikan (improvement), sehingga berdasarkan data dan informasi yang diperoleh oleh supervisor dapat dilakukan perbaikan kinerja guru sebagaimana mestinya dan akhirnya dapat meningkatkan kualitas kinerja guru dalam melaksanakan tugas mengajar.

Rendahnya kinerja mengajar guru secara umum yang dapat berakibat menimbulkan dampak negatif terhadap hasil belajar siswa dapat dilihat dari beberapa kondisi seperti berikut, adanya guru yang bekerja diluar jam kerja dengan dalih untuk pemenuhan kebutuhan sehari-hari yang berdampak pada kurangnya waktu yang digunakan untuk membaca serta melakukan aktivitas yang dapat meningkatkan kemampuan guru; ditemukannya guru yang tidak melaksanakan kegiatan belajar mengajar tanpa adanya kejelasan; kurangnya kedisiplinan guru pada saat jam kerja; masih adanya guru yang tidak membuat rencana pembelajaran, guru belum memaksimalkan sarana pendukung dalam penyampaian materi. Faktor yang mempengaruhi kondisi diatas adalah seperti komunikasi, organisasi, supervisi kepala sekolah, etos kerja, motivasi, kesejahteraan guru, kepemimpinan kepala sekolah serta fasilitas pendidikan yang kurang diperhatikan yang berdampak pada kinerja guru yang tidak memuaskan.

Kegiatan pembelajaran merupakan kegiatan utama di sekolah untuk mewujudkan tujuan pendidikan., oleh karena itu efektivitas dan efisiensi dalam pembelajaran dapat tercapai. Sebagai supervisor adalah salah satu tugas kepala sekolah untuk menyupervisi pekerjaan yang sudah dilakukan oleh tenaga pendidik. Penyebab kinerja guru yang rendah bisa jadi disebabkan karena lemahnya proses pengawasan yang dilakukan oleh kepala sekolah. Pengawasan dapat memperbaiki atau bahkan meningkatkan mutu pembelajaran oleh karena itu diperlukan adanya supervisi. 


\section{PEMBAHASAN}

Menurut (Iwantoro, 2016) pendidikan berperan penting dalam mewujudkan adanya peningkatan sumber daya manusia. Pendidikan adalah suatu hal yang sangat penting dalam membangun bangsa dan negara. Negara yang dapat mengelola pendidikannya dengan baik maka negara tersebut akan semakin maju, oleh karena itu pendidikan dapat menyiapkan sumber daya manusia yang mampu membangun peradaban bangsa. Perbaikan dan meningkatkan kinerja guru adalah salah satu cara untuk meningkatkan sumber daya manusia yang pengoptimalannya perlu adanya supervisi supaya tujuan pendidikan dapat tercapai.

Supervisi dalam arti sebagai pengawasan menurut (Norhasni \& Affero, 2011) dapat diartikan sebagai dua cara dari proses interaksi yang siswa dan supervisornya diperlukan untuk terlibat. Dalam pelaksanaan tugasnya, kepala sekolah harus mengerahkan seluruh masyarakat yang ada di lingkungan sekolah. Tujuan umum supervisi akademik adalah untuk mengembangkan situasi pembelajaran yang lebih baik melalui pembinaan dan peningkatan profesi mengajar; melalui supervisi pembelajaran diharapkan kualitas pengajaran dilakukan oleh guru semakin meningkat, baik dalam mengembangkan kemampuan, yang selain ditentukan oleh seorang guru, juga pada peningkatan komitmen, kemauan, dan motivasi yang dimiliki guru tersebut.

Menurut (Sabandi, 2013)secara umum supervisi dikenal dilakukan oleh supervisor dengan melakukan kunjungan ke kelas. Memeriksa persiapan guru mengajar dan mengomentari persiapan mengajar yang dibuat oleh guru adalah tugas supervisor. Kemudian mengamati proses mengajar dan mencatat segala sesuatu berkenaan dengan pelaksanaan pembelajaran yang dilakukan oleh guru. Supervisor kemudian akan membicarakan dengan guru perihal hasil pengamatannya.; mengomentari guru perihal apa saja yang perlu ditingkatkan. Namun seringkali supervisi dilakukan hanya sampai pada tahap memeriksa rencana pembelajaran atau tahap mengamati proses pelaksanaan pembelajaran guru ketika di kelas.

(Nuchiyah, 2007) mengatakan bahwa kepala sekolah yang berperan dalam mensupervisi pembelajaran adalah salah satu upaya dari peningkatan dari pembelajaran efektif di sekolah. Kepala sekolah sebagai pemimpin bisa dikatakan sebagai penentu dari keberhasilan program pengajaran yang ada di sekolah. Faktor penting dalam mempengaruhi prestasi kerja suatu organisasi adalah kepemimpinan. Sebagai pemimpin pendidikan di sekolah, seorang kepala sekolah selain berfungsi sebagai administrator juga berfungsi sebagai supervisor yang intinya memberi layanan professional dalam meningkatkan kompetensi profesional guru maupun kepala sekolah, baik secara langsung maupun secara tidak langsung. 
Fungsi kepala sekolah merupakan salah satu faktor penting dalam menumbuhkan jabatan guru melalui supervisi yang dilakukan di sekolah. Dengan adanya koordinasi kepala sekolah, guru dapat berkembang serta meningkatkan prestasi kerja menurut bidangnya masing-masing, selain itu kepala sekolah sebagai pemimpin pendidikan di sekolah harus selalu mengawasi, dan mengontrol seluruh kegiatan-kegiatan guru dan bawahan lainnya di sekolah, sehingga akan tercapai tujuan yang diinginkan. Berhasil atau tidaknya seorang guru sangat dipengaruhi oleh adanya supervisi dari kepala sekolah. Dengan demikian kepala sekolah sebagai pemimpin di sekolah dituntut agar memiliki kemampuan dan keterampilan tentang supervisi.

Kepala sekolah harus bertanggung jawab terhadap kemajuan guru-guru. Ia harus sanggup memberikan bantuan kepada guru-guru agar para guru dapat mengerti dan dapat memberikan penilaian terhadap kecenderungan-kecenderungan keinginan yang ada dalam masyarakat setempat, sehingga tujuan pendidikan dapat tercapai. Dalam meningkatkan proses belajar mengajar guru harus saling memberi dan menerima informasi dengan Kepala Sekolah, sehingga seluruh tugas-tugasnya akan berjalan selain itu diperlukan bentuk hubungan dan kerja sama berdasarkan kedudukan sejajar, Kepala Sekolah, komite sekolah dan semua warga sekolah perlu menjunjung tinggi hubungan kerja sama demi mewujudkan tujuan pendidikan, ini berarti bahwa bahwa kepala sekolah maupun komite sekolah dalam menjalankan tugasnya tidak saling mendominasi satu sama lain, tidak saling melanggar wewenang masing-masing tapi saling bahu-membahu berdasarkan aturan yang ditetapkan.

Persepsi baik seorang guru terhadap supervisi akademik kepala sekolah dapat terlihat dari baiknya kualitas mengajar seorang guru. Sebaliknya, kurang baiknya kualitas mengajar guru adalah salah satu implementasi dari persepsi buruk guru terhadap supervisi akademik kepala sekolah. Hal ini dapat terjadi karena terabaikannya saran dan masukan dari supervisor. Dalam melaksanakan aktivitas-aktivitas di sekolah, tentu terdapat perbedaan-perbedaan antara guru yang satu dengan yang lainnya. Dalam hal ini Kepala Sekolah sangat diharapkan agar mampu mengkoordinir seluruh tugas-tugas guru dan bawahan lainnya di sekolah, terutama dalam proses belajar-mengajar sehingga seluruh kegiatan akan berjalan lancar. Tugas ini sudah dilaksanakan oleh pemimpin pendidikan, walaupun secara menyeluruh belum semuanya. Sifat-sifat kelalaian dan ketidakmampuan kepala sekolah tidak dapat dibiarkan terus-menerus begitu saja, karena hal itu dapat mempengaruhi kelancaran kegiatan belajar mengajar di sekolah.

Berdasarkan uraian diatas, terlihat bahwa peran dan pengaruh yang diberikan oleh supervisi akademik kepalas sekolah sangat penting terhadap kinerja guru. Supervisi akademik selain sebagai tugas kepala sekolah juga sekaligus memberikan pengaruh terhadap kualitas kinerja guru yang didapatkan dari perbaikan dan pembinaan aspek pembelajaran yang dibutuhkan oleh guru sekaligus memberikan 
dorongan berupa moral sehingga guru selalu mengingat tugas utamanya yaitu melakukan peningkatan kualitas mengajar.

\section{KESIMPULAN}

Untuk dapat meningkatkan kinerja mengajar guru, perlu adanya dukungan dari berbagai pihak. Berjalannya seluruh aktivitas di sekolah sangat besar pengaruhnya pada pimpinan sekolah itu sendiri. Karena itu supervisi kepala sekolah terhadap guru dalam melaksanakan tugas merupakan salah satu pengaruh dalam memperlancar proses kegiatan di sekolah. Yang berdampak akan meningkatnya kinerja mengajar guru dapat terlaksana, sehingga dapat memberikan dampak yang positif terhadap kualitas pembelajaran.

\section{SARAN}

1. Kepada guru hendaknya meningkatkan kinerjanya bukan hanya karena adanya pengawasan dari kepala sekolah melainkan dengan keinginan dari dalam diri sendiri.

2. Kepada kepala sekolah hendaknya melakukan supervisi kelas secara berkala dan teratur dengan pendekatan personal.

3. Kepala sekolah hendaknya meningkatkan kualitas kepemimpinannya untuk memberikan pengaruh yang positif kepada bawahannya, sehingga seluruh warga sekolah merasa nyaman berada di lingkungan sekolah.

\section{DAFTAR PUSTAKA}

Iwantoro, I. (2016). Kompetensi Supervisi Kepala Sekolah Meningkatkan Kinerja Guru Dalam Rangka Mencapai Tujuan Pendidikan. Jurnal Pendidikan Islam, III(1), 1-11.

Norhasni, Z. A., \& Affero, I. (2011). Effective Supervisory Approach in Enhancing Postgraduate Research Studies. International Journal of Humanities and Social Science, 1(2), 206-217.

Nuchiyah, N. (2007). Pengaruh Kepemimpinan Kepala Sekolah dan Kinerja Mengajar Guru Terhadap Prestasi Belajar Siswa. JURNAL, Pendidikan Dasar, V(7)(April), 1-4. Retrieved from http://file.upi.edu/Direktori/JURNAL/PENDIDIKAN_DASAR/Vol._V_No._7_April_2007/Pengaru

h_Kepemimpinan_Kepala_Sekolah_dan_Kinerja.pdf [accessed: Feb 25, 2011] 
Sabandi, A. (2013). Supervisi Pendidikan Untuk Pengembangan Profesionalitas Guru Berkelanjutan. Jurnal Ilmiah Ilmu Pendidikan, XIII(2), 1-9. 